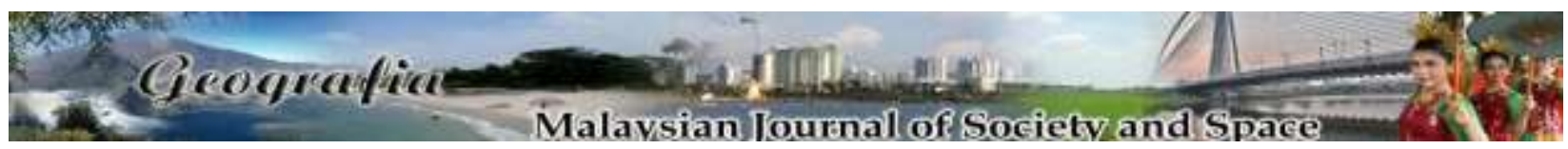

\title{
Tahap kesejahteraan penduduk di pinggiran wilayah metropolitan: Kajian kes koridor utara negeri Selangor, Malaysia
}

\author{
Yazid Saleh, Hanifah Mahat, Mohmadisa Hashim, Nasir Nayan, Samsudin Suhaili, \\ Saiyidatina Balkhis Norkhaidi, Irfan Azim Mohd Zanuddin \\ Jabatan Geografi \& Alam Sekitar, Fakulti Sains Kemanusiaan, \\ Universiti Pendidikan Sultan Idris, Malaysia. \\ Correspondence: Yazid Saleh (yazid@fsk.upsi.edu.my)
}

Received: 05 September 2019; Accepted: 12 December 2019; Published: 28 August 2020

\begin{abstract}
Abstrak
Kesejahteraan hidup adalah keadaan seseorang individu atau kumpulan. Ia boleh diukur dengan menyelidik keadaan sosioekonomi penduduk/kumpulan tersebut. Artikel ini bertujuan mengenalpasti tahap bagi kesejahteraan hidup penduduk di kawasan Koridor Utara Selangor, Wilayah Metropolitan Lanjutan (WML) Lembah Klang-Langat. Kajian melibatkan 400 orang responden melibatkan ketua isi rumah sahaja yang menetap di sekitar kawasan pinggiran Koridor Utara Selangor bagi WML Lembah Klang-Langat. Pemilihan responden adalah dengan menggunakan kaedah pensampelan rawak mudah. Instrumen soal selidik berskala Likert 1 hingga 5 digunakan sebagai instrumen kajian. Berdasarkan indeks kesejahteraan hidup, pelbagai angkubah yang telah disenaraikan secara menyeluruh melibatkan kesejahteraan hidup namun dalam kajian ini pengkaji menggunakan empat pemboleh ubah iaitu perumahan, pengangkutan, sosioekonomi dan guna tanah. Pemboleh ubah perumahan terdiri daripada tiga sub pemboleh ubah iaitu pemilihan kawasan, keselamatan dan kemudahan. Manakala pemboleh ubah pengangkutan mempunyai dua sub pemboleh ubah iaitu pengangkutan awam dan perhubungan pengangkutan. Diikuti dengan sub pemboleh ubah sosioekonomi iaitu sosial dan ekonomi. Seterusnya bagi guna tanah, sub pemboleh ubah terdiri daripada jenis aktiviti dan pemilikan harta. Hasil kajian menunjukkan tahap kebolehpercayaan soal selidik boleh diterima dengan nilai alfa Cronbach setiap pemboleh ubah adalah lebih besar daripada 0.8 . Tahap bagi pengangkutan dan sosioekonomi berada pada tahap tinggi manakalah perumahan dan guna tanah berada pada tahap sederhana. Dapatan ini membuktikan bahawa tahap sesetengah kesejahteraan masyarakat berada pada tahap tinggi dan sederhana disebabkan perebakan yang berlaku. Ini bermakna manusia akan melakukan pelbagai penyesuaian terhadap persekitaran supaya persekitaran yang wujud selari dengan naluri manusia.
\end{abstract}

Kata kunci: kesejahteraan hidup, Koridor Utara Selangor, kualiti hidup, Lembah Klang, Lembah Langat, penduduk, Wilayah Metropolitan Lanjutan 
GEOGRAFIA Online ${ }^{\mathrm{TM}}$ Malaysian Journal of Society and Space 16 issue 3 (121-134)

(C) 2020, e-ISSN 2682-7727 https://doi.org/10.17576/geo-2020-1603-10

\title{
Population well-being levels in extended metropolitan region: A case study of Selangor northern corridor, Malaysia.
}

\begin{abstract}
Well-being is the the condition of an individual or group. It can be measured by study their socioeconomic condition. This article seeks to identify the levels of well-being of residents of Selangor Northern Corridor, Lembah Klang-Langat Extended Metropolitan Region (EMR). The study involved 400 respondents consisting of the heads of household in peri-urban areas of Selangor Northern Corridor of Lembah Klang-Langat EMR. Respondents were selected via a simple random sampling method. A 1-5 Likert scale questionnaire was used as a research instrument. Based on the well-being index, a variety of variables involving well-being were listed, although the author of this study used four variables, namely housing, transportation, socioeconomic environment and land use. The housing variable consisted of three sub-variables, comprising area selection, safety and facilities. The transport variable included two subvariables: public transportation and transportation network. The socioeconomic variables society and economy, while the sub-variables for land use were types of activities and property ownership. The study results indicate that the questionnaire's reliability level was acceptable as the Cronbach's alpha value of each variable exceeded 0.8. Transportation and socioeconomic environment stood at high levels, while housing and land use were at moderate levels. These findings demonstrate that the level of some of the community's well-being was high or moderate due to urban sprawl. This means that humans will adapt to the environment in various ways in order that it can accord with human needs.
\end{abstract}

Keywords: well-being, northern corridor of Selangor, quality of live, Klang valley, Langat valley, resident, Extended Metropolitan Region

\section{Pengenalan}

Kawasan pinggir bandar di seluruh dunia khususnya negara di Asia Tenggara semakin menghadapi cabaran berhadapan dengan pembangunan yang drastik. Pembangunan atau transformasi merupakan elemen penting dalam kemajuan sesebuah negara yang sering kali dikaitkan dengan proses transformasi dari satu keadaan kepada satu keadaan dapat mempengaruhi aspek kesejahteraan penduduk contohnya seperti pertukaran kawasan guna tanah daripada tradisional kepada moden ke arah yang lebih baik dengan melihat kepada aspek perindustrian, guna tanah, pertumbuhan ekonomi dan sistem pengangkutan (Abdul Samad, 2010; Bing-Sheng, 2016; Delik, Haryo, \& Woltjer, 2007; Katiman, 2007).

Secara ringkasnya, pembangunan merupakan satu perubahan yang dilaksanakan bagi membantu memudahkan kesejahteraan manusia menjadi lebih sempurna dan selesa untuk mencapai satu tingkat kehidupan yang lebih baik. Berdasarkan penjelasan tersebut, ternyata proses pembangunan begitu penting bagi sesebuah negara yang sedang membangun bagi proses kelangsungan hidup penduduk. Pada dasarnya, kunci utama rebakan perbandaran ke kawasan pinggiran adalah disebabkan oleh kepadatan pembangunan yang telah tepu di bandar-bandar utama selain daripada kebebasan guna tanah yang luas (Samruhaizad \& Azahan, 2014). 
GEOGRAFIA Online ${ }^{\mathrm{TM}}$ Malaysian Journal of Society and Space 16 issue 3 (121-134)

(C) 2020, e-ISSN 2682-7727 https://doi.org/10.17576/geo-2020-1603-10

Rebakan bandar umumnya adalah merupakan suatu proses peluasan kawasan perbandaran sesebuah bandar raya ke kawasan pinggir bandar yang lazimnya masih berkepadatan rendah, bersifat desa dengan guna tanah utamanya pertanian (Barnes et al., 2001). Pada skala bandar raya metropolitan, rebakan bandar dikatakan berlaku apabila kadar perubahan guna tanah pertanian kepada bukan pertanian termasuk kawasan binaan mengatasi kadar pertumbuhan penduduknya. Sejak dahulu lagi, proses pembangunan dan pembandaran di Malaysia banyak dipengaruhi oleh perkembangan ekonomi dalam sektor pembuatan dan kadar pertumbuhan ekonomi negara khususnya melalui sektor perindustrian menjadi perlahan ekoran daripada krisis kewangan yang melanda rantau Asia sedekad yang lalu (Katiman, 2006b).

Perubahan transformasi di negara yang sedang membangun terutama di kawasan yang kurang maju menyebabkan kawasan ini mengalami perubahan. Misalnya di Malaysia, pembangunan di kawasan luar bandar pada mulanya berasaskan kepada sektor pertanian. Kawasan luar bandar banyak bergantung kepada kayu bakar untuk memasak dan menggunakan sel kering dan minyak tanah untuk pencahayaan pada waktu malam dan secara tidak langsung dapat memelihara alam sekitar (Ivy, 2017). Selepas mencapai kemerdekaan, ekonomi yang sedia ada terus berkembang dengan sektor perlombongan yang makin giat dibangunkan diikuti dengan pembangunan bagi sektor perkhidmatan, infrastruktur dan perkembangan industri baru.

Perkembangan kawasan pinggiran amat penting dilihat kerana proses yang berlaku mempunyai pengaruh yang besar dan ketara kepada kesejahteraan hidup masyarakat. Keadaan ini dapat dilihat sejak berabad-abad dahulu sehingga ke hari ini ini. Menurut McGee (1991), perkembangan bandar bagi negara sedang membangun dengan negara maju adalah berbeza. Contohnya, negara-negara Eropah telah mengalami transformasi yang dimulai dengan zaman revolusi industri pada akhir abad ke-18 di mana bentuk ekonomi telah berubah daripada pertanian kepada pembuatan yang menghasilkan pelbagai teknologi baharu yang lebih produktif dan menjimatkan masa (Fatimah, 2005). Pembangunan kawasan pinggir bandar dan luar bandar pada asasnya telah membawa perubahan yang positif kepada kumpulan masyarakat dalam komuniti luar bandar.

\section{Kesejahteraan Hidup Penduduk Pinggiran}

Masyarakat pinggiran merupakan masyarakat kampung yang menikmati pelbagai pemondenan dari segi infrastruktur hasil daripada perkembangan yang pesat membangun di kawasan teras. Segala kelengkapan serta kemudahan mudah disalurkan ekoran daripada ketersampaian serta jangkauan kemudahan yang diperuntukkan di kawasan bandar. Masyarakat pinggiran menjalani kehidupan aktiviti harian dengan persekitaran suasana kampung di samping menikmati kemudahan moden perbandaran yang disediakan (Samruhaizad \& Azahan, 2014) dan kehidupan masyarakat di kawasan pinggiran ini tidak sesibuk di kawasan bandar.

Justeru, pembangunan yang dilakukan di pinggir bandar pasti mengalami perubahan akibat arus pemodenan yang dilaksanakan di sekitar kawasan serta kota metropolitan tersebut. Sedikit sebanyak proses rebakan pastinya memberi impak sama ada negatif atau positif. Buruk dan baik perubahan pembangunan tersebut hanya mampu dinilai oleh masyarakat setempat yang menduduki kawasan pinggir bandar sebelum dan selepas rebakan perbandaran berlaku. 
GEOGRAFIA Online ${ }^{\mathrm{TM}}$ Malaysian Journal of Society and Space 16 issue 3 (121-134)

(C) 2020, e-ISSN 2682-7727 https://doi.org/10.17576/geo-2020-1603-10

\section{Perumahan}

Pertambahan penduduk yang pesat memberi kesan terhadap kesejahteraan penduduk. Ini dapat dilihat melalui permintaan dan penawaran rumah kediaman khususnya daripada segi bekalan, kuantiti dan kualiti rumah yang diperlukan (Katiman et al., 2006a). Perluasan kawasan perumahan berlaku dengan begitu drastik terutama selepas Dasar Ekonomi Baru (DEB) dilancarkan (Shaharudin et al., 2016) dan kawasan perumahan digunapakai sebagai petunjuk kepada pembangunan dengan kehidupan manusia sebagai tempat tinggal. Malah, menurut Shaharudin et al. (2008), kemudahan yang terdapat sekitar kawasan perumahan menjadi tumpuan kepada penduduk dan pengujung contohnya taman rekreasi yang menjadi tempat interaksi sosial dalam memupuk perpaduan antara kaum di Malaysia. Hal ini demikian kerana keadaan persekitaran perumahan yang kondusif membolehkan hubungan interaksi antara masyarakat semakin baik.

Dalam artikel ini, perumahan menggambarkan tentang struktur fizikal yang boleh dilihat dan dikenali sebagai tempat kediaman kepada seseorang individu dan keluarga. Selain itu, ia turut berfungsi sebagai tempat perlindungan kepada manusia dari segala ancaman dan bahaya. Penyelidik menggunapakai petunjuk perumahan bagi melihat kesejahteraan penduduk pinggiran kerana pembangunan perumahan amat berkait rapat dengan proses transformasi di Malaysia tidak kira di kawasan teras, luar bandar mahupun kawasan pinggiran (Katiman et al., 2016). Sebagai contoh Molly, Kai dan Peter (2007) menjelaskan bahawa pada tahun 2007 lebih daripada 50 juta penduduk dunia berpindah ke kawasan bandar dan pinggir bandar setiap tahun untuk meningkatkan kesejahteraan hidup. Hujah ini diperkuatkan lagi oleh McGee (2009) berkata bahawa secara statistiknya banyak penduduk mula memecahkan sempadan bandar dan terus berkembang ke kawasan pinggiran menyebabkan kepadatan perumahan semakin meningkat seiring dengan penambahan pelbagai kemudahan fungsi dan keselamatan.

\section{Pengangkutan}

Bagi Katiman (2001) dan Christiaensen et.al (2013), perkembangan kawasan pinggiran bagi aspek kemudahan asas, pengangkutan dan komunikasi merupakan suatu proses penting penumpuan penduduk untuk mendiami kawasan tersebut. Kini, masyarakat lebih suka menetap di kawasan pinggiran kerana mobiliti kepada ruang ekonomi dan sosial lebih luas berbanding dengan kesibukan di tengah bandar. Sejak kebelakangan ini, proses rebakan bandar berlaku dengan pesat. Ini akan memberi kesan kepada perkembangan kawasan desa dan bandar kecil yang terletak di zon pinggiran wilayah metropolitan seperti Banting, Salak Tinggi, Sungai Pelek, Tanjung Sepat, Jenjarum, Telok Panglima Garang, Semenyih, Dengkil, Sepang dan Nilai di Koridor Selatan Selangor; dan Rawang, Serendah, Batang Berjuntai, Batang Kali dan Rasa di Koridor Utara Selangor. Dengan kadar pertumbuhan penduduk rata-rata tinggi melebihi 6.0 peratus (Kementerian Perumahan dan Kerajaan Tempatan, 2016) kadar ini jauh mengatasi kadar pertumbuhan penduduk Kuala Lumpur bagi tempoh yang sama.

Dalam konteks kajian ini, pengangkutan dilihat dari aspek darjah ketersampaian dan keselesaan. Hal ini demikian kerana pada masa kini, pembinaan mod pengangkutan yang pelbagai adalah untuk memberi pilihan yang lebih banyak kepada rakyat untuk memilih mod pengangkutan mengikut kemampuan, keselesaan, dan keselamatan mereka. Pengangkutan juga dilihat sebagai batu loncatan untuk melonjakkan pembangunan ekonomi ke tahap yang lebih tinggi selaras dengan matlamat untuk meningkatkan pengeluaran barangan dan perkhidmatan, 
GEOGRAFIA Online ${ }^{\mathrm{TM}}$ Malaysian Journal of Society and Space 16 issue 3 (121-134)

(C) 2020, e-ISSN 2682-7727 https://doi.org/10.17576/geo-2020-1603-10

penjanaan, guna tenaga dan pembangunan masyarakat seluruhnya (Abd Rahim, 2002). Sebagai contohnya melihat kepada kajian Katiman et al., (2011a) di Bandar Baru Nusajaya, Johor darjah ketersampaian dan mobiliti penduduk untuk menjalankan aktiviti harian serta mendapatkan bekalan bertambah semakin baik dengan wujudnya sistem perhubungan jalan raya yang baik. Selain itu, kemudahan pengangkutan yang ada membolehkan aliran pergerakan terutama penduduk yang menetap di kawasan pinggiran untuk pergi dan balik kerja di kawasan teras mahupun luar bandar (Abdul Rahman, 2011; Yazid et al., 2017). Peningkatan terhadap kemudahan pengangkutan awam dan sistem perhubungan memberi makna pergerakan penduduk bertambah baik serta darjah ketersampaian kepada aktiviti harian juga bertambah. Justeru, banyak masa perjalanan dapat dijimatkan dan dimanfaatkan untuk kegunaan lain dengan meluangkan masa bersama keluarga dan peluang ini secara tidak langsung dapat meingkatkan kesejahteraan hubungan kekeluargaan. Bagi Katiman et al., (2006) dan Deden (2017), sistem perhubungan yang cekap akan meningkatkan kesejateraan psikologi dan fisiologi seterusnya membawa kepada kesejahteraan kesihatan penduduk. Sengupta, Dipankar dan Bhisma (2007) juga merumuskan bahawa kesejahteraan penduduk di India semakin meningkat dengan pembangunan sistem pengangkutan jalan raya yang baik.

\section{Sosioekonomi}

Dalam melihat perubahan berkaitan kehidupan penduduk individu mahupun komuniti, persekitaran sosioekonomi perlu ditekankan. Menurut Todaro (1989), petunjuk sosioekonomi ialah berkaitan dengan kesihatan, pendidikan, pendapatan dan mentaliti manakala James dan David (1995) menjelaskan petunjuk sosial adalah berkaitan dengan demografi, kemiskinan, pendidikan, kesihatan dan perumahan. Di samping itu, perbezaan sosioekonomi dapat dibezakan dengan pengkelasan secara agregat atau komposit mahupun tidak agregat. Penggunaan petunjuk sosioekonomi lebih bersesuaian dalam mengukur kesejahteraan hidup daripada membandingkan pelbagai petunjuk yang berlainan. Katiman et al., (2011) mendapati di kawasan pinggiran Metropolitan Johor Baharu telah berlaku impak sosioekonomi yang bersifat segera seperti penduduk kehilangan suasana kehidupan tradisional, penempatan semula ke kawasan bandar baru, perubahan pekerjaan isi rumah dan peningkatan pendapatan bulanan. Begitu juga dari segi peningkatan kualiti rumah kediaman dan ketersampaian kepada kemudahan perkhidmatan sosial. Sebahagian besar isi rumah yang terlibat dengan projek tersebut telah dapat menikmati kehidupan yang lebih selesa setelah tinggal di bandar baru tersebut. Kajian tersebut juga mendapati bahawa masalah keselamatan belum lagi menjadi ancaman kepada kehidupan mereka dan hubungan kejiranan masih lagi rapat. Walau pun begitu ramai yang merasakan bahawa tahap amalan agama, terutamanya dalam kalangan remaja kian menurun. Majoriti mengamalkan agama pada tahap sederhana dan ramai juga yang tidak ambil peduli.

Selanjutnya, bagi ekonomi pula keadaan ekonomi inilah yang menjadi faktor yang asas dalam mengukur taraf pencapaian serta tahap sesebuah kawasan. Dapat dilihat pada masa yang sama pendapatan penduduk mula berubah ekoran daripada aktiviti perniagaan skala besar seperti TESCO dan GIANT, selain pasar raya saiz sederhana seperti Mydin, Warta dan Econsave (Katiman, 2006a; Samruhaizad \& Azahan, 2014). Kenyataan ini juga disokong oleh Yazid et. al. (2014) yang mendapati bahawa perubahan fungsi penawaran yang bersifat lebih global seperti pasar raya besar, penghantaran cepat dan pertambahan bilangan hotel telah mempengaruhi proses globalisasi. Keadaan ini menggambarkan bahawa semakin banyak perubahan penawaran fungsi iaitu perubahan dari tradisional kepada moden, semakin kuat pengaruh globalisasi. Situasi ini 
GEOGRAFIA Online ${ }^{\mathrm{TM}}$ Malaysian Journal of Society and Space 16 issue 3 (121-134)

(C) 2020, e-ISSN 2682-7727 https://doi.org/10.17576/geo-2020-1603-10

menyebabkan WML Lembah Klang-Langat kini mula tersebar dan memberikan kesan melampaui kawasan pinggiran. Di samping itu, petunjuk ekonomi ini juga sangat berkait rapat dengan isu kemiskinan dan tahap kemiskinan penting dalam pengukuran kesejahteraan masyarakat bagi kawasan pinggiran kerana berkait dengan kemampuan ekonomi isi rumah bagi memenuhi keperluan asas.

\section{Guna Tanah}

Menurut kajian yang dilakukan oleh Rodinelli dan Ruddle (1978), transformasi pembangunan kawasan pinggir lebih berfokus untuk mengubah kawasan tersebut menjadi lebih baik untuk penduduk setempat dengan memastikan bahawa semua penduduk sekitar mendapat kemudahan asas infrastruktur dan perkhidmatan sosial yang berkualiti. Selain terdapat ruang yang berkembang, sesuatu kawasan itu sekurang-kurangnya perlu mempunyai barangan dan perkhidmatan asas secara cekap bagi membantu memajukan penduduk yang tinggal seperti hospital, sekolah, pengangkutan awam dan klinik-klinik kesihatan. Kajian terhadap kawasan pinggiran yang bukan dalam konteks wilayah metropolitan oleh Haryati dan Nurasyikin (2013) terhadap pembangunan di Pekan Parit Raja, Johor mendapati berlaku transformasi daripada sebuah pekan kecil-tradisi kepada sebuah bandar yang menumpukan kepada pelbagai aktiviti penduduk yang mencakupi aspek pendidikan, sosial, ekonomi, politik dan infrastruktur. Transformasi pembangunan Pekan Parit Raja, Johor ini adalah disebabkan kewujudan beberapa institusi pendidikan terutamanya Universiti Tun Hussein Onn Malaysia (UTHM).

Dalam konteks kajian ini, penyelidik menilai guna tanah merupakan salah satu petunjuk yang mempengaruhi kesejahteraan penduduk bagi kawasan WML Lembah Klang-Langat dengan melihat jenis aktiviti yang berlaku dan pemilikan harta. Bagi kawasan di Lembah Langat, transformasi yang berlaku telah menyumbangkan ke arah pertumbuhan ekonomi yang semakin berkembang. Menurut Shaharudin et al. (2007), dalam tempoh empat dasawarsa ini dapat dilihat melalui perubahan guna tanah yang telah berlaku iaitu dari tahun 1966 sehinggalah tahun 2002. Perkembangan ekonomi yang baik di satu-satu kawasan pasti menyebabkan hasil peningkatan pendapatan penduduknya. Dengan merujuk kepada Nurasyikin (2013), keadaan ini sekaligus menyebabkan kadar pemilikan harta dan jenis aktiviti turut meningkat malah boleh dijadikan sub-petunjuk kepada kesejahteraan penduduk. Kajian daripada Katiman et al., (2010) mendapati bahawa tiga kategori utama bagi guna tanah di Lembah Langat telah berkembang dengan pesat iaitu kawasan pertanian, kawasan hutan dan kawasan tepu bina. Perkembangan ini didorong oleh perdagangan dan pelaburan luar secara langsung (foreign direct investment) yang berpangkalan di luar negara seperti Amerika Syarikat, Britain, Australia, Jepun, Korea dan Hong Kong.

\section{Metod Kajian}

Kajian ini menggunakan kaedah kuantitatif dengan menggunakan soal selidik sebagai instrumen kajian. Pemilihan kaedah kuantitatif ini kerana melibatkan responden yang ramai, lebih luas dan menyeluruh (Ary, Jacobs, \& Asghar, 2002). 


\section{Populasi dan Sampel Kajian}

Kajian melibatkan 400 orang responden yang merupakan sampel yang di pilih melalui pensampelan rawak mudah seperti mana saranan Krejcie dan Morgan (1970) iaitu bagi populasi melebihi 1,000,000 seramai 387 orang sampel yang perlu diambil. Namun dalam kajian ini, 400 orang sampel dipilih bagi mendapatkan bilangan yang genap. Pemilihan responden adalah dalam kalangan ketua isi rumah yang menetap di lokasi pusat petempatan kecil di Koridor Utara Selangor iaitu Bukit Beruntung, Batang Kali, Rasa, Kuala Kubu Baru, Kerling, Kalumpang dan Ulu Bernam (Rajah 1).

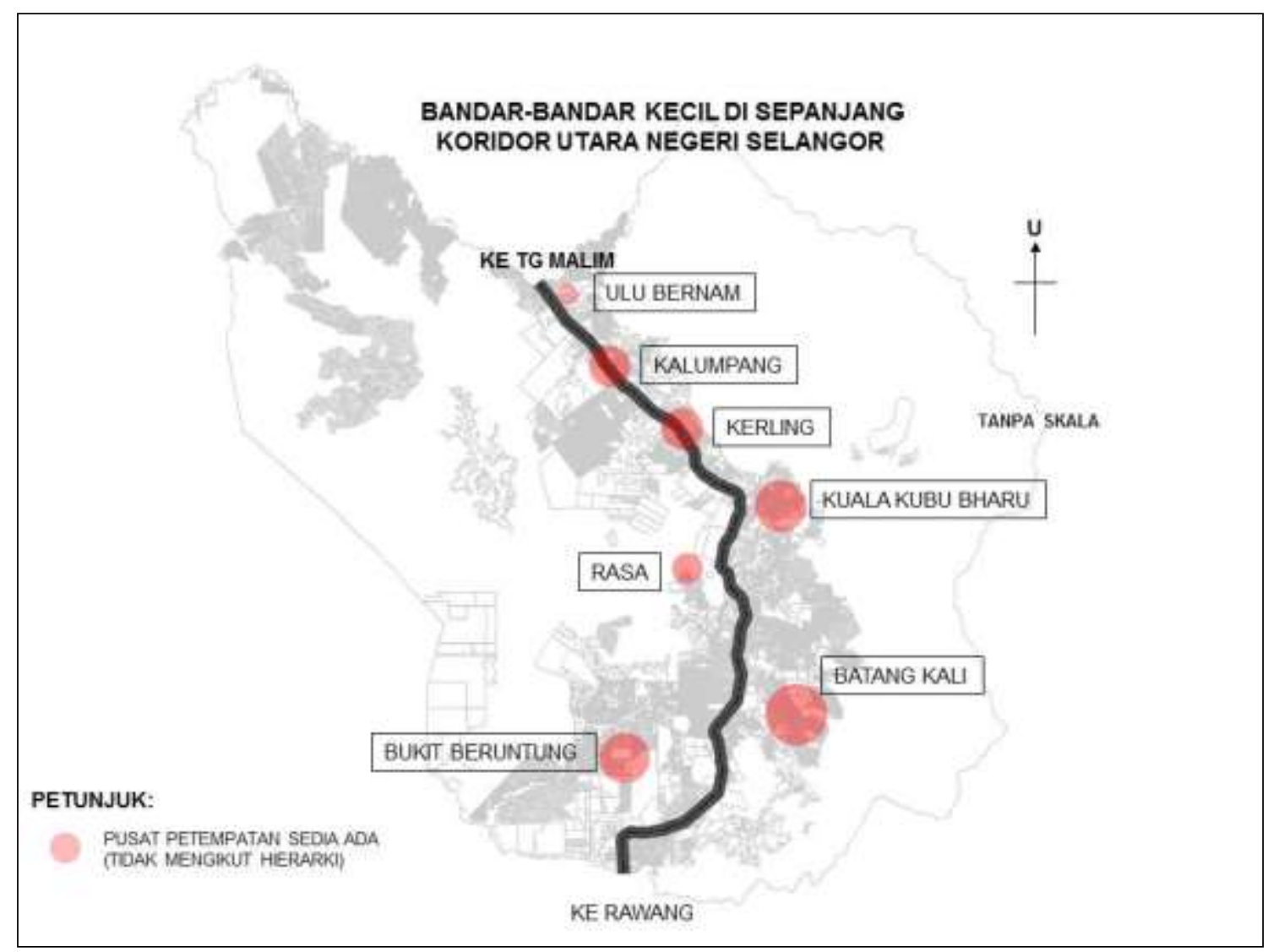

Rajah 1. Kawasan kajian di sepanjang koridor utara negeri Selangor

\section{Instrumen Kajian}

Borang soal selidik telah digunakan sebagai instrumen dalam kajian ini. Item soal selidik telah dipecahkan kepada dua bahagian iaitu bahagian latar belakang responden dan konstruk kesejahteraan (Jadual 1). Skala pengukuran item bagi setiap pemboleh ubah adalah dengan menggunakan skala Likert 5 mata iaitu 1=Sangat tidak setuju, $2=$ Tidak setuju, $3=$ Sederhana, $4=$ Setuju dan 5=Sangat setuju. 
Jadual 1. Instrumen kajian

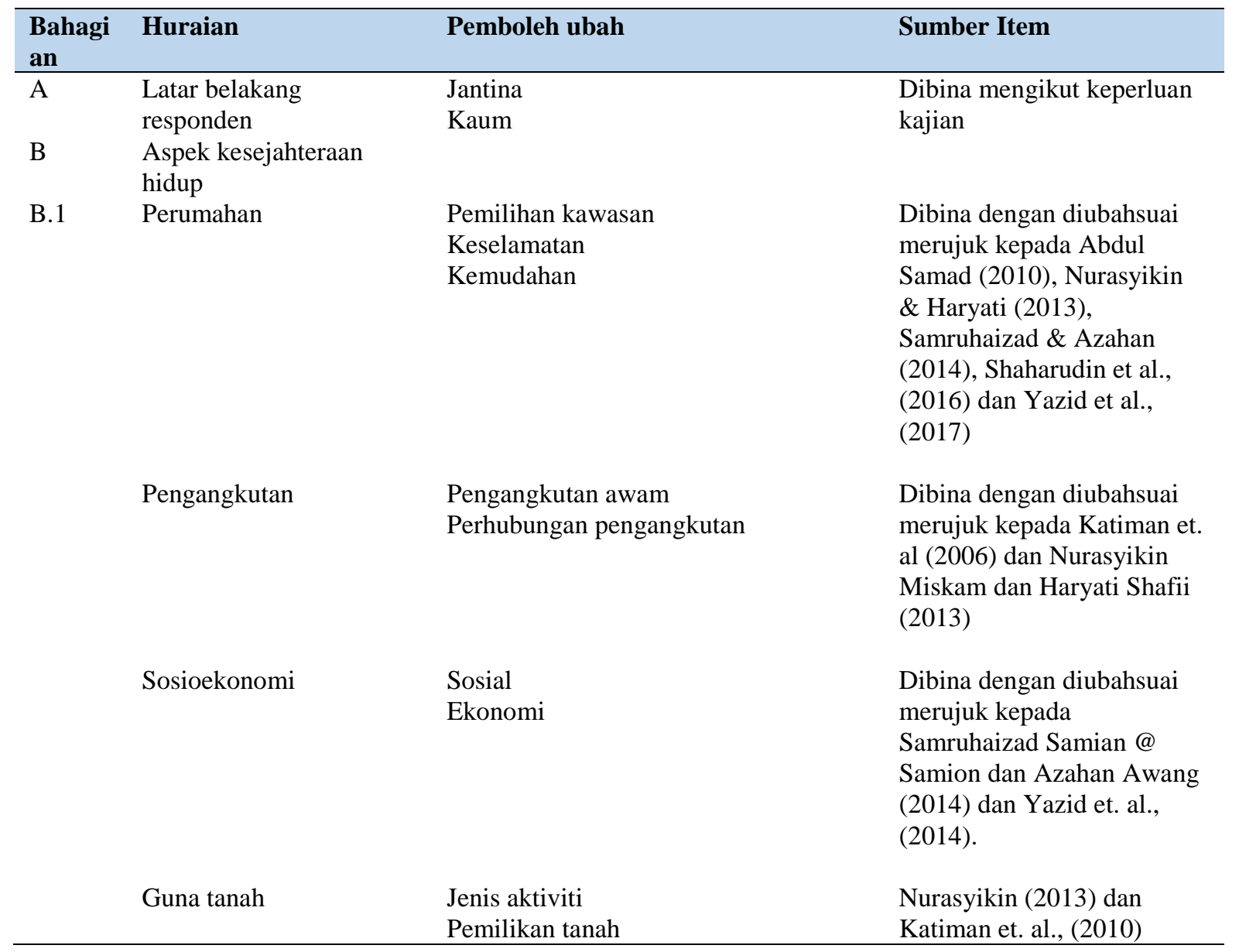

Jadual 2 menunjukkan nilai kebolehpercayaan Alpha Cronbach bagi keempat-empat pemboleh ubah yang melebihi 0.7 iaitu aras yang boleh diterima menurut Hair, Black, Babin, Anderson, dan Tatham (2006).

Jadual 2. Nilai kebolehpercayaan item kajian

\begin{tabular}{lll}
\hline Pemboleh ubah & Bilangan item & Nilai Alpha Cronbach \\
\hline Perumahan & 18 & 0.904 \\
Pengangkutan & 16 & 0.880 \\
Sosioekonomi & 11 & 0.808 \\
Guna tanah & 15 & 0.855 \\
\hline
\end{tabular}

\section{Dapatan dan Perbincangan}

Perbincangan dapatan kajian dibahagikan kepada dua bahagian iaitu latar belakang responden dan kesejahteraan hidup responden. Latar belakang responden melibatkan jantian responden dan kaum responden. Bagi tahap kesejahteraan pula, dapatan dibahagikan mengikut empat pemboleh ubah kajian iaitu perumahan, pengangkutan, sosioekonomi dan guna tanah. 
GEOGRAFIA Online ${ }^{\mathrm{TM}}$ Malaysian Journal of Society and Space 16 issue 3 (121-134)

(C) 2020, e-ISSN 2682-7727 https://doi.org/10.17576/geo-2020-1603-10

Jadual 3 menunjukkan latar belakang responden yang terdiri daripada 400 orang ketua isi rumah yang menetap di koridor utara WML Lembah Klang Langat. Seramai 230 orang (57.5\%) adalah lelaki dan 170 orang (42.5\%) adalah perempuan.

Jadual 3. Latar belakang responden

\begin{tabular}{llll}
\hline Latar Belakang Responden & $\mathbf{N}$ & $\mathbf{\%}$ \\
\hline Jantina & Lelaki & 230 & 57.5 \\
& Perempuan & 170 & 42.5 \\
& Jumlah & 400 & 100.0 \\
& & & \\
\multirow{4}{*}{ Kaum } & Melayu & 277 & 69.3 \\
& Cina & 58 & 14.5 \\
& India & 65 & 16.3 \\
& Jumlah & 400 & 100.0 \\
\hline
\end{tabular}

\section{Tahap Kesejahteraan Hidup Penduduk}

Kajian ini melibatkan empat pemboleh ubah kesejahteraan hidup iaitu perumahan, pengangkutan, sosioekonomi dan guna tanah. Bagi perumahan terdapat tiga sub pemboleh ubah iaitu pemilihan kawasan, keselamatan dan kemudahan. Manakala bagi pengangkutan terdapat dua sub pemboleh ubah iaitu perhubungan pengangkutan dan pengangkutan awam. Seterusnya bagi sosioekonomi, sub pemboleh ubah ialah sosio dan ekonomi. Bagi pemboleh ubah terakhir iaitu guna tanah, terdapat dua sub pemboleh ubah iaitu jenis aktiviti dan pemilikan tanah.

Analisis tahap konstruk indikator perumahan, pengangkutan, sosioekonomi dan guna tanah melibatkan analisis secara deskriptif iaitu min, peratus, sisihan piawai dan tahap secara keseluruhan. Tahap dalam kajian ini adalah berdasarkan nilai yang dibahagikan kepada tiga tahap iaitu rendah (skor 1.00-2.33), tahap sederhana (skor 2.34-3.66) dan tahap tinggi (skor 3.675.00). Analisis tahap pemboleh ubah kajian melibatkan (i) tahap perumahan, (ii) tahap pengangkutan, (iii) tahap sosioekonomi dan (iv) tahap guna tanah.

Berdasarkan jadual 4 memperlihatkan pemboleh ubah tahap perumahan secara keseluruhan iaitu pada tahap rendah 1 orang (0.3\%), tahap sederhana 234 orang (58.5\%) dan tahap tinggi seramai 165 orang (41.3\%). Ini jelas menunjukkan tahap konstruk perumahan responden keseluruhannya adalah pada tahap tinggi (min=3.71 dan $\mathrm{SP}=0.39$ ). Bagi sub pemboleh ubah tahap perumahan iaitu pemilihan kawasan, keselamatan dan kemudahan, dapatan menunjukkan tahap responden berapa pada tahap sederhana. Dapatan ini selari dengan Katiman et al., (2011b) yang menyatakan bahawa kecenderungan masyarakat untuk memilih kawasan perumahan yang mempunyai kemudahan asas dan keselamatan dapat meningkatkan kesejahteraan hidup.

Jadual 4. Tahap perumahan

\begin{tabular}{|c|c|c|c|c|c|c|c|c|c|}
\hline \multirow[t]{2}{*}{$\begin{array}{l}\text { Pemboleh } \\
\text { ubah }\end{array}$} & \multicolumn{2}{|c|}{$\begin{array}{l}\text { Tahap } \\
\text { Rendah }\end{array}$} & \multicolumn{2}{|c|}{$\begin{array}{l}\text { Tahap } \\
\text { Sederhana }\end{array}$} & \multicolumn{2}{|c|}{ Tahap Tinggi } & \multirow[t]{2}{*}{ Min } & \multirow[t]{2}{*}{ SP } & \multirow[t]{2}{*}{$\begin{array}{l}\text { Tahap } \\
\text { Purata }\end{array}$} \\
\hline & $\mathrm{N}$ & $\%$ & $\mathrm{~N}$ & $\%$ & $\mathrm{~N}$ & $\%$ & & & \\
\hline Perumahan & 1 & 0.3 & 234 & 58.5 & 165 & 41.3 & 3.71 & 0.39 & Tinggi \\
\hline $\begin{array}{l}\text { - Pemilihan } \\
\text { kawasan }\end{array}$ & 6 & 1.5 & 202 & 50.5 & 192 & 48.0 & 3.70 & 0.56 & Tinggi \\
\hline
\end{tabular}


GEOGRAFIA Online ${ }^{\mathrm{TM}}$ Malaysian Journal of Society and Space 16 issue 3 (121-134)

(C) 2020, e-ISSN 2682-7727 https://doi.org/10.17576/geo-2020-1603-10

\begin{tabular}{llllllllll} 
- Keselamatan & 9 & 2.3 & 250 & 62.5 & 141 & 35.3 & 3.57 & 0.53 & Sederhana \\
- Kemudahan & 5 & 1.3 & 147 & 36.8 & 248 & 62.0 & 3.85 & 0.45 & Tinggi \\
\hline
\end{tabular}

Jadual 5 memperlihatkan dapatan pemboleh ubah pengangkutan secara keseluruhan, sub pemboleh ubah perhubungan pengangkutan memperlihatkan purata tinggi dan sub pemboleh ubah pengangkutan awam juga mempunyai tahap purata tinggi. Keseluruhan tahap purata bagi konstruk ini ialah tahap tinggi. Keadaan ini menggambarkan bahawa pengangkutan di koridor utara WML Lembah Klang Langat berada dalam keadaan yang baik. Hal ini dapat dibuktikan oleh kajian yang dilakukan Dargaye et al., (2007) dalam kajiannya mendapati pertumbuhan pengangkutan di negara membangun akan berkembang dengan pesat selari dengan perkembangan ekonomi negara yang secara tidak langsung dapat menjamin kesejahteraan hidup penduduk. Malah, Bing-Sheng (2016) juga menjelaskan bahawa faktor penting yang mengakibatkan kesejahteraan penduduk kawasan pinggiran adalah infrastruktur yang maju seperti rangkaian pengangkutan di WML Lembah Klang Langat yang dapat meningkatkan kebolehtersampaian dan memudahkan urusan seharian penduduk.

Jadual 5. Tahap pengangkutan

\begin{tabular}{|c|c|c|c|c|c|c|c|c|c|}
\hline \multirow[t]{2}{*}{ Pemboleh ubah } & \multicolumn{2}{|c|}{$\begin{array}{l}\text { Tahap } \\
\text { Rendah }\end{array}$} & \multicolumn{2}{|c|}{$\begin{array}{l}\text { Tahap } \\
\text { Sederhana }\end{array}$} & \multicolumn{2}{|c|}{$\begin{array}{l}\text { Tahap } \\
\text { Tinggi }\end{array}$} & \multirow[t]{2}{*}{ Min } & \multirow[t]{2}{*}{ SP } & \multirow[t]{2}{*}{$\begin{array}{l}\text { Tahap } \\
\text { Purata }\end{array}$} \\
\hline & $\mathrm{N}$ & $\%$ & $\mathrm{~N}$ & $\%$ & $\mathrm{~N}$ & $\%$ & & & \\
\hline Pengangkutan & 3 & 0.8 & 9.3 & 18.0 & 360 & 90.0 & 3.99 & 0.40 & Tinggi \\
\hline $\begin{array}{l}\text { - Pengangkutan } \\
\text { awam }\end{array}$ & 12 & 3.0 & 239 & 59.8 & 149 & 37.3 & 3.64 & 0.51 & Tinggi \\
\hline $\begin{array}{l}\text { - Perhubungan } \\
\text { Pengangkutan }\end{array}$ & 2 & 0.5 & 29 & 7.3 & 369 & 92.3 & 4.28 & 0.42 & Tinggi \\
\hline
\end{tabular}

Seterusnya ialah tahap bagi konstruk sosioekonomi. Merujuk kepada jadual 6, tahap bagi pemboleh ubah sosioekonomi ialah tinggi. Dapatan bagi sub pemboleh ubah sosial dan ekonomi penduduk turut berada pada tahap tinggi. Hasil dapatan ini juga selari dengan penemuan Katiman et al., (2011) di kawasan pinggiran Metropolitan Johor Baharu yang mendapati berlaku impak sosioekonomi yang bersifat segera seperti perubahan pekerjaan isi rumah dan peningkatan pendapatan bulanan. Malah, Yazid et al., (2014) turut menyatakan bahawa perubahan fungsi sosioekonomi yang berlaku di kawasan pinggiran dapat meningkatkan kesejahteraan hidup penduduk dan memenuhi keperluan asas.

Jadual 6. Tahap konstruk sosioekonomi

\begin{tabular}{|c|c|c|c|c|c|c|c|c|c|}
\hline \multirow[t]{2}{*}{ Pemboleh ubah } & \multicolumn{2}{|c|}{$\begin{array}{l}\text { Tahap } \\
\text { Rendah }\end{array}$} & \multicolumn{2}{|c|}{$\begin{array}{l}\text { Tahap } \\
\text { Sederhana }\end{array}$} & \multicolumn{2}{|c|}{$\begin{array}{l}\text { Tahap } \\
\text { Tinggi }\end{array}$} & \multirow[t]{2}{*}{ Min } & \multirow[t]{2}{*}{ SP } & \multirow[t]{2}{*}{$\begin{array}{l}\text { Tahap } \\
\text { Purata }\end{array}$} \\
\hline & $\mathrm{N}$ & $\%$ & $\mathrm{~N}$ & $\%$ & $\mathrm{~N}$ & $\%$ & & & \\
\hline Sosioekonomi & 2 & 0.5 & 32 & 8.0 & 366 & 91.5 & 4.16 & 0.40 & Tinggi \\
\hline - Sosial & 2 & 0.5 & 41 & 10.3 & 357 & 89.3 & 4.20 & 0.46 & Tinggi \\
\hline - Ekonomi & 3 & 0.8 & 71 & 17.8 & 326 & 81.5 & 4.13 & 0.48 & Tinggi \\
\hline
\end{tabular}

Bagi konstruk guna tanah pula, tahap bagi konstruk ini ialah sederhana. Berdasarkan jadual 7, sub konstruk jenis aktiviti mempunyai tahap purata yang tinggi dan sub konstruk pemilikan tanah juga mempunyai tahap yang tinggi. Dapatan ini selari dengan Katiman et al., (2010) yang menyatakan bahawa guna tanah di kawasan pinggiran telah berubah menjadi bandar kecil dan 
persekitaran fizikal kawasan kediaman telah berubah dari tradisional kepada moden dan menjadikan persekitaran menarik dengan pelbagai aktiviti.

Jadual 7. Tahap konstruk guna tanah

\begin{tabular}{|c|c|c|c|c|c|c|c|c|c|}
\hline \multirow[t]{2}{*}{ Pemboleh ubah } & \multicolumn{2}{|c|}{$\begin{array}{l}\text { Tahap } \\
\text { Rendah }\end{array}$} & \multicolumn{2}{|c|}{$\begin{array}{l}\text { Tahap } \\
\text { Sederhana }\end{array}$} & \multicolumn{2}{|c|}{$\begin{array}{l}\text { Tahap } \\
\text { Tinggi }\end{array}$} & \multirow[t]{2}{*}{ Min } & \multirow[t]{2}{*}{ SP } & \multirow[t]{2}{*}{$\begin{array}{l}\text { Tahap } \\
\text { Purata }\end{array}$} \\
\hline & $\mathrm{N}$ & $\%$ & $\mathrm{~N}$ & $\%$ & $\mathrm{~N}$ & $\%$ & & & \\
\hline Guna Tanah & 2 & 0.5 & 149 & 37.3 & 249 & 62.3 & 3.80 & 0.42 & Tinggi \\
\hline - Jenis Aktiviti & 3 & 0.8 & 107 & 26.8 & 290 & 72.5 & 3.91 & 0.47 & Tinggi \\
\hline - Pemilikan Tanah & 11 & 2.8 & 157 & 39.3 & 232 & 58.0 & 3.67 & 0.54 & Tinggi \\
\hline
\end{tabular}

Secara keseluruhannya, dapatan kajian menunjukkan majoriti sub pemboleh ubah kajian berada pada tahap tinggi (Rajah 2). Ini menunjukkan bahawa tahap kesejahteraan penduduk bagi kawasan koridor utara WML Lembah Klang Langat berada pada tahap yang membanggakan.

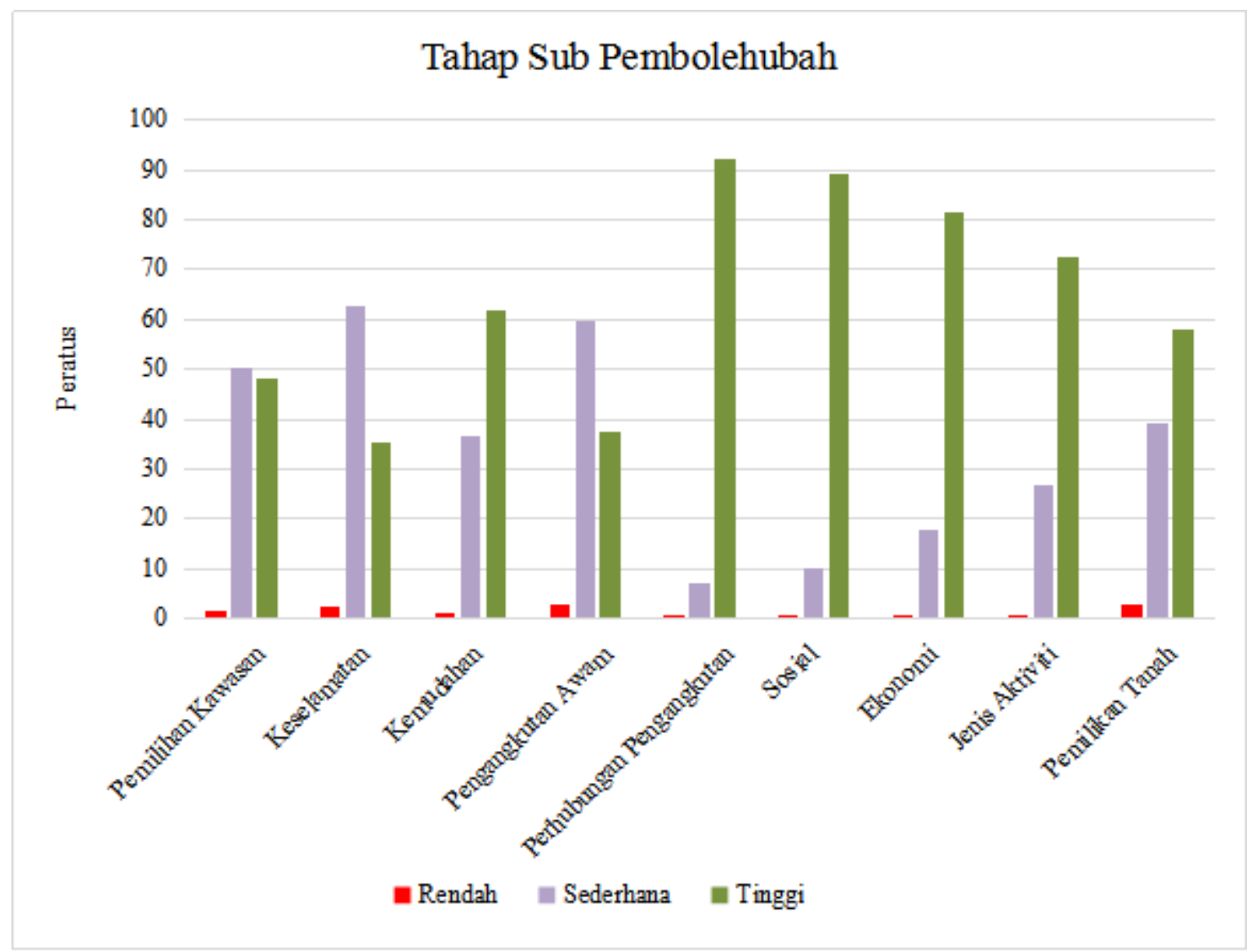

Rajah 2. Tahap keseluruhan sub pemboleh ubah kajian

\section{Kesimpulan}

Kajian ini menunjukkan tahap kesejahteraan penduduk bagi pemboleh ubah perumahan, pengangkutan, sosioekonomi dan guna tanah berada pada tahap yang tinggi secara keseluruhannya kecuali sub pemboleh ubah perumahan iaitu keselamatan berada pada tahap 
GEOGRAFIA Online ${ }^{\mathrm{TM}}$ Malaysian Journal of Society and Space 16 issue 3 (121-134)

sederhana. Keadaan ini jelas memberikan gambaran yang positif selari dengan inisiatif kerajaan dalam mentransformasikan kawasan pinggiran berdasarkan Rancangan Malaysia ke-10 iaitu membawa pembangunan ke luar bandar dengan menjaga kesejahteraan hidup penduduk. Senario ini menambahkan lagi kepesatan proses pembangunan bagi kawasan pinggiran yang seterusnya mendatangkan pelbagai kesan positif kepada isi rumah yang menetap di kawasan pinggir bandar seperti peningkatan peluang pekerjaan, kemudahan awam dan aksessibiliti semakin baik.

\section{Penghargaan}

Perbincangan dalam artikel ini adalah sebahagian penemuan dari penyelidikan yang berjudul 'Pembinaan Petunjuk Transformasi Desa Bandar di Pinggir Wilayah Metropolitan Lanjutan Lembah Klang-Langat' tajaan Geran Top Down Kementerian Pengajian Tinggi 2016 (20160238-106-41).

\section{Rujukan}

Abd Rahim, A. R. (2002). Pengajaran dan pembelajaran sains sosial: Teori dan amalan. Kuala Lumpur: Universiti Malaya.

Abdul Rahman, E. (2011). Pembandaran dan Kehidupan Bandar di Semenanjung Malaysia. Akademika, 81(2), 23-39.

Abdul Samad, H. (2010). Urbanisasi di Malaysia: Mengaitkan kepelbagaian proses ke bentuk perbandaran. Malaysian Journal of Environmental Management, 11(2), 21-31.

Ary, D., Jacobs, L. C., \& Asghar, R. (2002). Introduction to research in education (6th ed.). Belmont: Wadsworth.

Barnes, K.B., Morgan, J.M., Roberge, M.C. \& Lowe, S. (2001). Sprawl development: It spatterns, consequences and measurement. Towson University.

Bing-Sheng, W. (2016). Modeling impacts of globalization on desakota regions: A case study of Taipei Metropolitan Area. Environment and Planning B: Planning and Design, 43(2), 320340.

Christiaensen, L., Weerdt, J., \& Todo, Y. (2013). Urbanization and poverty reduction: The role of rural diversification and secondary towns. Agricultural Economics, 44(4-5), 435-447.

Dargay, J., Dermot, G., \& Martin, S. (2007). Vehicle ownership and income growth, worldwide: 1960-2030. The Energy Journal, 28(4), 143-170.

Deden, R. (2017). Rapid urbanization and the need for sustainable transportation policies in Jakarta. In IOP Conference Series: Earth and Environmental Science, 124(1), 12-17.

Delik, H., Haryo, W., \& Woltjer, J. (2007). Peri-Urbanisation in East Asia: A new challenge for planning? Journal International Development Planning Review, 29(4), 503-519.

Fatimah, D. (2005). Transformasi sosial: Evolusi atau revolusi. Kuala Lumpur: Universiti Malaya.

Hair, J. F., Black, W. C., Babin, B. J., Anderson, R. E., \& Tatham, R. L. (2006). Multivariate data analysis (6th ed.). New Jersey: Prentice Hall.

Haryati, S., \& Nurasyikin, M. (2013). Transformasi dan pembangunan luar bandar: Kesan ke atas penduduk dan persekitaran. International Journal of the Malay World and Civilisation (IMAN), 1(2), 71-81. 
GEOGRAFIA Online ${ }^{\mathrm{TM}}$ Malaysian Journal of Society and Space 16 issue 3 (121-134)

(C) 2020, e-ISSN 2682-7727 https://doi.org/10.17576/geo-2020-1603-10

Ivy, D. (2017). Principal component analysis of the determinants of spatial disparity between rural and urban localities of Ghana. International Journal of Social Economics, 44(6), 715731.

James, M., \& David, P. (1995). The fields and methods of social planning. Heinemen Educational Book, London.

Katiman, R. (2001). Dasar dan strategi petempatan dalam pembangunan negara. Bangi: Penerbit Universiti Kebangsaan Malaysia.

Katiman, R. (2006a). Migrasi ke kawasan pinggiran Wilayah Metropolitan Lembah Klang. Akademika, 68, 3-27. Diperoleh daripada http://myais.fsktm.um.edu.my/8593/

Katiman, R. (2006b). Pembandaran dan perkembangan wilayah metropolitan lanjutan Lembah Klang-Langat, Malaysia. Jurnal E-Bangi, 1(1), 1-27.

Katiman, R. (2007). Transformasi desa-bandar di pinggiran Wilayah Metropolitan: Beberapa bukti di sekitar Dengkil, Malaysia. Dalam Kertas Kerja yang dibentangkan di Seminar PKPPM (pp. 17-18). Sandy Beach Resort, Pulau Pinang: Universiti Sains Malaysia.

Katiman, R., Abdul Rahim, M. N., Er, A. C., Aishah@Eshah, M., Zaini, S., Mohd Hasan, N., \& Rosniza, A. (2011a). Impak pembangunan Bandar Baru Nusajaya Wilayah Iskandar Malaysia terhadap kesejahteraan hidup penduduk asal setempat. Geografia: Malaysian Journal of Society and Space, 7(5), 14-28.

Katiman, R., Abdul Rahim, M. N., Er, A. C., Aishah@Eshah, M., Zaini, S., Mohd Hasan, N., \& Rosniza, A. (2011b). Impak pembangunan Bandar Baru Nusajaya Wilayah Iskandar Malaysia terhadap kesejahteraan hidup penduduk asal setempat. Geografia: Malaysian Journal of Society and Space, 7(5), 14-25.

Katiman, R., Asmah, A., Sulong, M., Mohd Fuad, M. J., \& Mohd Azlan, A. (2006). Transformasi desa-bandar: Koridor Kemaman-Dungun, Terengganu. Bangi: Universiti Kebangsaan Malaysia.

Katiman, R., Mochamad, R., Choy, E. A., Abdul Rahim, M. N., Zaini, S., \& Norazuan, Md. H. Aishah@Esah, H. M. (2010). Pembandaran dan rebakan bandar di pinggir Wilayah Metropolitan Klang-Langat. Geografia : Malaysian Journal of Society and Space, 6(2), 3750.

Katiman, R., Mohd Fuad, M. J., \& Aishah @ Ecah, M. (2010). Migrasi keluar dan rebakan bandar: Bukti di pinggiran wilayah Metropolitan Lembah Klang, Malaysia. Geografia: Journal of Social Sciences and Humanities, 5(2), 184-198.

Kementerian Perumahan dan Kerajaan Tempatan. (2016). Dasar Perbandaran Negara Kedua. Putrajaya Malaysia: Kementerian Perumahan dan Kerajaan Tempatan.

Krejcie, R. V. \& Morgan, D. W. (1970). Determining sample size for research activities. Educational and Psychological Measurement, 30(3), 607-610.

McGee, T. G. (1991). The emergence of desakota regions in Asia: Expanding a hypothesis. The Extended Metropolis: Settlement Transition in Asia, 3-25.

McGee, T. G. (2009). The spatiality of urbanization: The policy challenges of Mega-Urban and Desakota regions of Southeast Asia. Japan.

Molly O’Meara, S., Kai, L., \& Peter, N. (2007). State of the World. Our Urban Future. London: Earthscan.

Nurasyikin, M. (2013). Transformasi Pekan Parit Raja: Kajian terhadap kesejahteraan hidup masyarakat. Universiti Tun Hussein Onn Malaysia. 
Nurasyikin, M., \& Haryati, S. (2013). Transformasi pembangunan luar bandar: Kesan ke atas kesejahteraan hidup masyarakat. Dalam Persidangan Geografi \& Alam Sekitar, 5-6 Mei 2013. Universiti Pendidikan Sultan Idris, Perak.

Rodinelli, D. A., \& Ruddle, K. (1978). Urbanization and rural development: A spatial policy for equitable growth. New York: Praeger Publisher.

Samruhaizad, S., \& Azahan, A. (2014). Isu perbandaran dan kualiti hidup penduduk pinggir bandar. International Journal of the Malay World and Civilisation, 2(1), 63-75.

Sengupta, R., Dipankor, C., \& Bhisma, R. (2007). Impact of a highway on the socio-economic well-being of rural households living in proximity. Contemporary Issues and Ideas in Social Sciences, 3(3), 1-10.

Shaharudin, I., Abdul Samad, H., Abdul Hadi, H. S., \& Ahmad Fariz, M. (2007). Kerja lapangan berterusan: Merungkai pembandaran lestari. Akademika, 71, 3-30.

Shaharudin, I., Abdul Samad, H., Abdul Hadi, H. S., \& Ahmad Fariz, M. (2008). Spatial urban metabolism for liveable city. Blueprints for Sustainable Infrastructure Conference. Dalam The New Zealand Society for Sustainability Engineering and Science (NZSSES). Auckland, New Zealand.

Shaharudin, I., Abdul Samad, H., Ruslan, R., \& Abdul Hadi, H. S. (2016). Transformasi dan dayahuni perumahan di Malaysia. In M. J. Jamaluddin, H. Abdul Samad, M. Ahmad Fariz, \& A. Kadaruddin (Eds.), Transformasi dan dayahuni habitat manusia (pp. 157-174). Malaysia: UKM.

Todaro, M. P. (1989). Development economic in the third world (4th ed.). New York, Longman. Yazid, S., Mohamad Suhaily Yusri, C. N., Mohmadisa, H., Nasir, N., \& Kamarul, I. (2014). Impak globalisasi terhadap perubahan fungsi bandar kecil: Beberapa penemuan di Batang Kali dan Bukit Beruntung, Selangor. Geografi, 2(2), 28-38.

Yazid, S., Mohmadisa, H., Hanifah, M., \& Nasir, N. (2017). Issues of rural-urban transformation on the fringe of metropolitan region: Several findings from the Selangor Northern Corridor, Malaysia. International Journal of Academic Research in Business and Social Sciences, 7(6), 913-924. 